\title{
Multiple Calcium Export Exchangers and Pumps Are a Prominent Feature of Enamel Organ Cells
}

\author{
Sarah Y. T. Robertson ${ }^{1}$, Xin Wen ${ }^{1}$, Kaifeng Yin ${ }^{1}$, Junjun Chen ${ }^{1,2,3}$, Charles E. Smith ${ }^{4}$ and \\ Michael L. Paine ${ }^{1 *}$ \\ ${ }^{1}$ Center for Craniofacial Molecular Biology, Herman Ostrow School of Dentistry, University of Southern California, \\ Los Angeles, CA, United States, ${ }^{2}$ Department of Oral Medicine, Shanghai Ninth People's Hospital, Shanghai Jiao Tong \\ University School of Medicine, Shanghai, China, ${ }^{3}$ Shanghai Key Laboratory of Tumor Microenvironment and Inflammation, \\ Department of Biochemistry and Molecular Cell Biology, Shanghai Jiao Tong University School of Medicine, Shanghai, China, \\ ${ }^{4}$ Department of Anatomy and Cell Biology, Faculty of Medicine, McGill University, Montreal, QC, Canada
}

OPEN ACCESS

Edited by:

Steven Joseph Brookes, Leeds Dental Institute, United Kingdom

Reviewed by:

Petros Papagerakis, University of Michigan, United States

Felicitas B. Bidlack

Forsyth Institute, United States Javier Catón,

CEU San Pablo University, Spain

*Correspondence: Michael L. Paine paine@usc.edu

Specialty section:

This article was submitted to Craniofacial Biology and Dental

Research,

a section of the journal

Frontiers in Physiology

Received: 13 March 2017

Accepted: 08 May 2017

Published: 23 May 2017

Citation:

Robertson SYT, Wen X, Yin K, Chen J, Smith CE and Paine ML (2017) Multiple Calcium Export Exchangers and Pumps Are a Prominent Feature of Enamel Organ Cells. Front. Physiol. 8:336 doi: 10.3389/fphys.2017.00336
Calcium export is a key function for the enamel organ during all stages of amelogenesis. Expression of a number of ATPase calcium transporting, plasma membrane genes (ATP2B1-4/PMCA1-4), solute carrier SLC8A genes (sodium/calcium exchanger or NCX1-3), and SLC24A gene family members (sodium/potassium/calcium exchanger or NCKX1-6) have been investigated in the developing enamel organ in earlier studies. This paper reviews the calcium export pathways that have been described and adds novel insights to the spatiotemporal expression patterns of PMCA1, PMCA4, and NCKX3 during amelogenesis. New data are presented to show the mRNA expression profiles for the four Atp2b1-4 gene family members (PMCA1-4) in secretory-stage and maturation-stage rat enamel organs. These data are compared to expression profiles for all Slc8a and Slc24a gene family members. PMCA1, PMCA4, and NCKX3 immunolocalization data is also presented. Gene expression profiles quantitated by real time PCR show that: (1) PMCA1, 3, and 4, and NCKX3 are most highly expressed during secretory-stage amelogenesis; (2) NCX1 and 3, and NCKX6 are expressed during secretory and maturation stages; (3) NCKX4 is most highly expressed during maturation-stage amelogenesis; and (4) expression levels of PMCA2, NCX2, NCKX1, NCKX2, and NCKX5 are negligible throughout amelogenesis. In the enamel organ PMCA1 localizes to the basolateral membrane of both secretory and maturation ameloblasts; PMCA4 expression is seen in the basolateral membrane of secretory and maturation ameloblasts, and also cells of the stratum intermedium and papillary layer; while NCKX3 expression is limited to Tomes' processes, and the apical membrane of maturation-stage ameloblasts. These new findings are discussed in the perspective of data already present in the literature, and highlight the multiplicity of calcium export systems in the enamel organ needed to regulate biomineralization.

Keywords: amelogenesis, biomineralization, calcium channels, calcium exchangers, calcium pumps 


\section{INTRODUCTION}

Enamel is the hardest and most calcified tissue in mammals, and understanding enamel formation is crucial for developing strategies to repair or regenerate it (Smith, 1998; Hubbard, 2000; Lacruz et al., 2013). Amelogenesis, the process of enamel development, can be divided into the secretory and maturation stages with a brief pre-secretory stage before the secretory stage and a transition stage between the secretory and maturation stages. Epithelial-derived enamel-forming cells (ameloblasts) differentiate from the inner enamel epithelium (IEE) during the pre-secretory stage (Orrenius et al., 2015). These amelobasts are highly polarized with an apical end that faces the enamel area and a basal end that faces the blood circulation. During the secretory stage, ameloblasts migrate away from the dentin while synthesizing and secreting enamel matrix proteins (EMPs) such as amelogenin, ameloblastin, and enamelin into the enamel area from Tomes' processes at their apical ends. These EMPs serve as a scaffold for the orientation and elongation of enamel hydroxyapatite (Hap) crystals (Smith, 1998). Each enamel rod follows a single ameloblast's Tomes' process with the interrod following the border of the cell, giving enamel its characteristic rod-interrod pattern (Skobe, 2006; Hu et al., 2007). There is a massive shift in gene expression during the transition stage, when approximately $25 \%$ of ameloblasts undergo apoptosis, after which another 25\% undergo apoptosis throughout the following stages of amelogenesis (Tsuchiya et al., 2009). During the maturation stage, the ameloblasts undergo cyclical changes between ruffle-ended (RA) and smooth-ended (SA) morphology (Smith, 1998; Lacruz et al., 2013). Maturation-stage ameloblasts become specialized for ion transport and resorptive activities, which includes the secretion of the protease KLK4 to aid in the degradation of EMPs that are subsequently removed through endocytosis (Smith, 1998; Lacruz et al., 2012a, 2013). The continuously growing incisor of mice makes it a good model for studying the chronological progression of amelogenesis. While general concepts of ion transport throughout amelogenesis have been well-studied and discussed elsewhere (Arquitt et al., 2002; Paine et al., 2007; Lyaruu et al., 2008; Bronckers et al., 2010, 2015; Josephsen et al., 2010; Yin et al., 2015), and in particular the transcellular calcium ion $\left(\mathrm{Ca}^{2+}\right)$ transport (reviewed in Nurbaeva et al., 2015b), in this paper we focus primarily on $\mathrm{Ca}^{2+}$ export.

\section{Overview-Calcium Transport}

In general high intracellular concentrations of calcium $\left(\mathrm{Ca}^{2+}\right)$ catalyze cell death signaling cascades, so cells maintain a gradient of $\sim 10^{-3} \mathrm{M} \mathrm{Ca}^{2+}$ concentration outside the cell, in the mitochondria, and in the endoplasmic reticulum (ER) where $\mathrm{Ca}^{2+}$ is stored; while in the cytoplasm, the concentration is $\sim 10^{-7} \mathrm{M}$ (Brini and Carafoli, 2011). The plasma membrane contains a variety of $\mathrm{Ca}^{2+}$ channels that transiently open to allow $\mathrm{Ca}^{2+}$ influx in response to plasma membrane voltage changes, ligand-receptor interaction, or emptying $\mathrm{Ca}^{2+}$ stores of the ER and mitochondria (Brini and Carafoli, 2011). Calcium is removed from the cytoplasm through a number of mechanisms including the SERCA pump that replenishes ER stores, the mitochondrial
$\mathrm{Ca}^{2+}$ uniporter, that replenishes mitochondrial stores, the plasma membrane low-affinity high capacity $\mathrm{Na}^{+} / \mathrm{Ca}^{2+}$ exchanger proteins (NCX), the $\mathrm{Na}^{+} / \mathrm{Ca}^{2+} \mathrm{K}^{+}$exchanger proteins (NCKX), and the high-affinity low-capacity plasma membrane $\mathrm{Ca}^{2+}$ ATPase (PMCA) pump proteins (Berridge et al., 2003; Brini and Carafoli, 2011; Hu et al., 2012; Bronckers et al., 2015).

Calcium $\left(\mathrm{Ca}^{2+}\right)$ transport is crucial to understand the process of amelogenesis because not only is unbound $\mathrm{Ca}^{2+}$ a major component of hydroxyapatite (Hap), $\mathrm{Ca}^{2+}$ can also act as a major signaling molecule capable of regulating cell processes in eukaryotic cells such as cell division, cell attachment, motility, survival, differentiation as well as gene expression (Hubbard, 1996; Blair et al., 2011).

\section{Calcium Extrusion}

The SLC8A (sodium/calcium exchangers or NCX), SLC24A (potassium-dependent sodium/calcium exchangers or NCKX), and ATP2B (ATPase plasma membrane $\mathrm{Ca}^{2+}$ transporting pumps or PMCA pumps) gene families of $\mathrm{Ca}^{2+}$ transporters mediate $\mathrm{Ca}^{2+}$ extrusion in most cell types (Brini and Carafoli, 2011), and proteins from all three of these families have been reported in enamel organ cells (Sasaki and Garant, 1986c; Borke et al., 1995; Zaki et al., 1996; Okumura et al., 2010; Hu et al., 2012; Wang et al., 2014). The SLC8A gene family has 3 members (NCX1-3) and all have a generally accepted stoichiometry of the extrusion of $1 \mathrm{Ca}^{2+}$ in exchange for the intrusion of $3 \mathrm{Na}^{+}$ (Brini and Carafoli, 2011), while the SLC24A gene family has 5 members (NCKX1-5) and extrudes $1 \mathrm{Ca}^{2+}$ and $1 \mathrm{~K}^{+}$in exchange for $4 \mathrm{Na}^{+}$, typically against the $\mathrm{Ca}^{2+}$ gradient; however, the directionality both NCX and NCKX exchangers can be reversed depending on the $\mathrm{Na}^{+}$and $\mathrm{Ca}^{2+}$ gradients (Jalloul et al., 2016b; Zhekova et al., 2016). SLC8A and SLC24A gene families are electrogenic because there is a translocation of net charge across the plasma membrane, have a low $\mathrm{Ca}^{2+}$ affinity, and are capable of transporting $\mathrm{Ca}^{2+}$ in bulk rapidly across the plasma membrane (Brini, 2009). They are reversible but in ameloblasts they likely operate in extruding $\mathrm{Ca}^{2+}$ from the cytoplasm facilitated by transport of $\mathrm{Na}^{+}$and $\mathrm{K}^{+}$down their gradients (Brini and Carafoli, 2011; Hu et al., 2012). PMCA pumps/proteins have 4 members (PMCA1-4, coded by genes ATP2B1-4) and are part of a larger family of genes, called P-type primary ion transport ATPases, that catalyze the auto-phosphorylation of a conserved aspartyl residue within the pump from ATP (Palmgren and Nissen, 2011).

\section{Calcium Extrusion-SLC8A and SLC24A Gene Products}

The SLC8A and SLC24A families are primarily expressed in excitable tissues such as muscle and heart, as their rapid bulk transport of $\mathrm{Ca}^{2+}$ is important in, for example, muscle and heart contraction (Brini and Carafoli, 2011). The SLC8A/NCX and SLC24A/NCKX transporters are $\mathrm{Na}^{+} / \mathrm{Ca}^{+}$exchangers and can be either $\mathrm{K}^{+}$-dependent (NCKX) or $\mathrm{K}^{+}$-independent (NCX) (Shumilina et al., 2010).

NCX1 is expressed in heart, brain, bladder, kidney, and cells of the enamel organ; NCX2 is expressed in brain and skeletal muscle; and NCX3 is expressed in brain, skeletal muscle and 
cells of the enamel organ (Lytton, 2007; Okumura et al., 2010; Lacruz et al., 2012b; Sharma and O'halloran, 2014). Okumura et al. demonstrated NCX1 and NCX3 expression at the apical pole of both secretory and maturation ameloblasts, and expression of NCX1 was also observed in cells of the stratum intermedium and papillary layer (Okumura et al., 2010). In addition, protein levels of NCX1 and NCX3 throughout amelogenesis remained relatively unchanged (Okumura et al., 2010). Using real-time PCR, Lacruz et al. confirmed that the mRNA levels of both NCX1 and NCX3 did not significantly change from secretory- to maturation-stage enamel organ cells (Lacruz et al., 2012b).

NCKX1 is expressed primarily in retinal rod photoreceptors and platelets (Schnetkamp, 2004; Lytton, 2007). NCKX2 is expressed in cone photoreceptors and is involved in mouse motor learning and memory (Schnetkamp, 2004; Lee et al., 2009, 2013), and NCKX3 is expressed in the brain and the kidneys (Schnetkamp, 2004; Lee et al., 2009) though it is expressed in the kidneys at higher levels in female mice than in male mice (Lee et al., 2009). NCKX3 is also highly expressed in the human endometrium during the menstrual cycle, where its expression is partially regulated by the steroid hormone $17 \beta$-estradiol (Yang et al., 2011). NCKX4 is expressed in olfactory neurons (Stephan et al., 2011), and also in the maturation-stage ameloblasts (Hu et al., 2012). NCKX5 is expressed in skin melanocytes, retinal epithelium, and brain (Schnetkamp, 2004; Lytton, 2007; Sharma and O'halloran, 2014; Jalloul et al., 2016a,b). NCKX6/NCLX was originally considered a member of the NCKX family but is now considered part of the $\mathrm{Ca}^{2+}$ cation (CCX) exchanger branch (Cai and Lytton, 2004; Sharma and O'halloran, 2014) as a mitochondrial membrane $\mathrm{Ca}^{2+}, \mathrm{Li}^{+} / \mathrm{Na}^{+}$ exchanger with a wide tissue distribution (Schnetkamp, 2004; Lytton, 2007; Sharma and O'halloran, 2014).

\section{Calcium Extrusion-ATP2B Gene Products}

The ATPase plasma membrane $\mathrm{Ca}^{2+}$ transporting (or PMCA) gene family is postulated to be involved in $\mathrm{Ca}^{2+}$ homeostasis, as it has a high affinity for $\mathrm{Ca}^{2+}$ but cannot transport $\mathrm{Ca}^{2+}$ as rapidly as either the NCX or NCKX transporters (Brini and Carafoli, 2011). The PMCA family is part of the superfamily of P-type ATPase pumps that form a stable phosphorylated intermediate as it hydrolyzes one molecule of ATP for each $\mathrm{Ca}^{2+}$ transported (Strehler and Zacharias, 2001; Cai and Lytton, 2004). The phosphorylated enzyme intermediate of the P-type ATPases, which include the SERCA family of transporters in the ER membrane (Giacomello et al., 2013), occurs between $\gamma$-phosphate of a hydrolyzed ATP with a D-residue in a highly conserved region of the ATPase pump (Brini and Carafoli, 2011).

PMCA1 is expressed in most tissues throughout development. Its expression is highest in the nervous system, heart, skeletal muscle, and intestine (Zacharias and Kappen, 1999), and regulated by growth factors such as glucocorticoids and Vitamin D (Zacharias and Kappen, 1999; Giacomello et al., 2013). PMCA2 is expressed mainly in the brain, heart, mammary glands and ear, and decreased expression of PMCA2 causes increased apoptosis in breast cancer cells (Curry et al., 2012; Giacomello et al., 2013). PMCA3 has the highest calmodulin affinity and is detected primarily in the brain and skeletal muscles
(Krebs, 2009; Giacomello et al., 2013). PMCA4 is involved in the fertilization process and cardiac function, and has been found to associate with lipid rafts, which often function to aggregate protein complexes important in signaling pathways (Giacomello et al., 2013). It has been suggested that PMCA4 is more involved in cell-specific $\mathrm{Ca}^{2+}$ signaling than as a pump for bulk $\mathrm{Ca}^{2+}$ export (Strehler, 2013; Brini et al., 2017). PMCA4 interacts with nitric oxide synthase and with calcineurin, which regulates NFAT signaling (Brini, 2009; Kim et al., 2012; Strehler, 2013).

PMCA1 and PMCA4 are important in osteoclast differentiation, maturity, and survival, and $A t p 2 b 1^{+/-}$and Atp $264^{-/-}$mice have decreased bone density due to an increased number of mature osteoclasts and increased osteoclast apoptosis (Kim et al., 2012). The PMCA family members can also influence $\mathrm{IP}_{3}$-mediated calcium signaling by binding to phosphatidylinositol-4,5-bisphosphate $\left(\mathrm{PIP}_{2}\right)$ on the plasma membrane as well as removing $\mathrm{Ca}^{2+}$ necessary for phospholipase C (PLC) activity, which prevents cleaving by PLC and thereby prevents $\mathrm{Ca}^{2+}$ release from the ER (Penniston et al., 2014). Altered PMCA expression is a characteristic of many cancers (Curry et al., 2011) and many other human diseases (Brini et al., 2013), but the diversity in isoforms and splicing and lack of specificity of small molecules to target PMCAs present challenges in therapeutic agent development (Strehler, 2013).

\section{Summary-Calcium Export Exchangers and Pumps in Amelogenesis}

There now are a number of reports that show expression and localization data for NCX1 and NCX3 (Okumura et al., 2010; Lacruz et al., 2012b), and NCKX4 (Hu et al., 2012; Wang et al., 2014) in the enamel organ. Reports on PMCA expression and activities throughout amelogenesis are scant (Sasaki and Garant, 1986c; Borke et al., 1995; Zaki et al., 1996), and to the authors' knowledge, the only investigations into the role of PMCA proteins in amelogenesis date back decades. Data presented here better defines the mRNA profiles of all SLC8A, SLC24A, and ATP2B gene family members, and adds additional insight into the protein and spatiotemporal expression profiles of NCKX3, PMCA1, and PMCA4.

\section{Calcium Export Exchangers and Pumps and Disease}

A number of the ATP2B, SLC8A, and SLC24A gene family members are linked to mammalian disease, but notably mutations to SLC24A4 are associated with non-syndromic amelogenesis imperfecta (AI) (Parry et al., 2013; Seymen et al., 2014; Wang et al., 2014; Herzog et al., 2015). A comprehensive list of the PMCA, NCX, and NCKX pumps and exchangers, their links to human pathologies, and mouse models of each gene is found in Table 1.

\section{MATERIALS AND METHODS}

\section{Animals}

All vertebrate animal manipulation was carried out in accordance with Institutional and Federal guidelines. The animal protocols were approved by the Institutional Animal Care and Use 
TABLE 1 | Pathologies associated with genes ATP2B1-4, SLC8A1-3 and SLC24A1-6.

\begin{tabular}{|c|c|c|c|c|c|}
\hline $\begin{array}{l}\text { Gene } \\
\text { symbol }\end{array}$ & $\begin{array}{l}\text { Protein } \\
\text { name }\end{array}$ & $\begin{array}{l}\text { Predominant } \\
\text { substrates }\end{array}$ & Link to human disease & Animal models & References \\
\hline ATP2B1 & PMCA1 & $\mathrm{Ca}^{2+}$ & & Embryonic lethal & Okunade et al., 2004 \\
\hline ATP2B2 & PMCA2 & $\mathrm{Ca}^{2+}$ & & Vestibular/motor imbalance, Deafness & Street et al., 1998; Bortolozzi et al., 2010 \\
\hline ATP2B3 & PMCA3 & $\mathrm{Ca}^{2+}$ & Spinocerebellar ataxia & & Bertini et al., 2000; Zanni et al., 2012 \\
\hline ATP2B4 & PMCA4 & $\mathrm{Ca}^{2+}$ & Familial spastic paraplegia & $\begin{array}{l}\text { No overt phenotype in Atp2b4 null mice, } \\
\text { Male mice are infertile }\end{array}$ & Okunade et al., 2004; Ho et al., 2015 \\
\hline SLC8A1 & NCX1 & $\mathrm{Na}^{+}, \mathrm{Ca}^{2+}$ & & Embryonic lethal & Wakimoto et al., 2000 \\
\hline SLC8A2 & NCX2 & $\mathrm{Na}^{+}, \mathrm{Ca}_{2}^{+}$ & & & \\
\hline SLC8A3 & NCX3 & $\mathrm{Na}^{+}, \mathrm{Ca}^{2+}$ & & $\begin{array}{l}\text { Skeletal muscle fiber necrosis, Defective } \\
\text { neuromuscular transmission }\end{array}$ & Sokolow et al., 2004 \\
\hline SLC8B1* & NCLX & $\mathrm{Na}^{+}, \mathrm{Li}^{+}, \mathrm{Ca}^{2+}$ & & & Khananshvili, 2013 \\
\hline SLC24A1 & NCKX1 & $\mathrm{Na}^{+}, \mathrm{Ca}^{2+}, \mathrm{K}^{+}$ & $\begin{array}{l}\text { Congenital stationary } \\
\text { night blindness }\end{array}$ & Night blindness & Riazuddin et al., 2010; Vinberg et al., 2015 \\
\hline SLC24A2 & NCKX2 & $\mathrm{Na}^{+}, \mathrm{Ca}^{2+}, \mathrm{K}^{+}$ & & & \\
\hline SLC24A3 & NCKX3 & $\mathrm{Na}^{+}, \mathrm{Ca}^{2+}, \mathrm{K}^{+}$ & & & \\
\hline SLC24A4 & NCKX4 & $\mathrm{Na}^{+}, \mathrm{Ca}^{2+}, \mathrm{K}^{+}$ & Amelogenesis imperfecta & Amelogenesis imperfecta & $\begin{array}{l}\text { Parry et al., 2013; Seymen et al., 2014; Wang } \\
\text { et al., 2014; Herzog et al., } 2015\end{array}$ \\
\hline SLC24A5 & NCKX5 & $\mathrm{Na}^{+}, \mathrm{Ca}^{2+}, \mathrm{K}^{+}$ & $\begin{array}{l}\text { Hypopigmentation, } \\
\text { Oculocutaneous albinism }\end{array}$ & & Mondal et al., 2012; Wei et al., 2013 \\
\hline SLC24A6 & NCKX6 & $\mathrm{Na}^{+}, \mathrm{Ca}^{2+}, \mathrm{K}^{+}$ & & & \\
\hline
\end{tabular}

Note that SLC8B1 is found in the mitochrodria of mammalian skeletal and heart muscle, neurons and a few other cell types.

Committee at the University of Southern California (Protocol \#20461).

\section{Quantitative PCR Analysis}

Secretory-stage and maturation-stage enamel organ cells from mandibular incisors of 4-week old Wistar Hanover rats were collected as previously described (Lacruz et al., 2012b; Wen et al., 2014), and RNA extraction was performed using a QIAshredder, an RNeasy Protect Mini Kit, and DNase I solution from Qiagen (Valencia, CA, USA). Reverse transcription and real-time PCR were performed using the iScript cDNA Synthesis kit and SYBR Green Supermix from BioRad, respectively. Real-time PCR was performed on the CFX96 system (BioRad Laboratories, Hercules, CA, USA) in $10 \mu \mathrm{l}$ volumes with a final primer concentration of $100 \mathrm{~nm}$, for 40 cycles at $95^{\circ} \mathrm{C}$ for $10 \mathrm{~s}$ and $58^{\circ} \mathrm{C}$ for $45 \mathrm{~s}$. Six independent real-time PCR analyses were conducted using samples from a total of 6 rats, 3 males, and 3 females, for each gene of interest (primers are listed in Table 2), and for both stages of amelogenesis. The male and female data were analyzed separately and no significant differences were noted between the sexes, so the data presented in the graph were generated from all 6 animals $(n=6)$. Rat enamel organ is preferred to mouse enamel organ for real-time PCR and western blot studies because separating secretory and maturation stage from adult mouse incisors is technically difficult and yields less RNA and protein per animal.

\section{Western Blot Analysis}

Secretory (S) and maturation (M) enamel organ cells from mandibular incisors of 4 -week old Wistar Hanover rats were collected. Brain (B) and heart $(\mathrm{H})$ tissues were also collected as control tissues. Total protein extraction was performed with RIPA buffer ( $1 \%$ Nonidet P-40, 0.1\% SDS, 0.5\% deoxycholic acid, $150 \mathrm{~mm} \mathrm{NaCl}, 50 \mathrm{~mm}$ Tris, $\mathrm{pH} \mathrm{8.0)}$ and protease inhibitor cocktail, complete mini (Roche Applied Sciences, Indianapolis, IN, USA). Samples were homogenized manually with a pestle six times, then sonicated with a BRANSON digital sonifier Model 450 (All-Spec Industries, Wilmington, NC, USA; 10\% intensity, $10 \mathrm{~s}$ on and $10 \mathrm{~s}$ off). Samples were then cleared by centrifugation $\left(15,000 \mathrm{~g}, 15 \mathrm{~min}, 4^{\circ} \mathrm{C}\right)$. Proteins were quantified using the bicinchoninic acid (BCA) assay (Pierce, Rockford, IL, USA) and equal quantities were loaded (15 $\mu \mathrm{g}$ per lane) onto $4-12 \%$ SDS-PAGE resolving gels. Protein was transferred to a PVDF membrane, then blocked with $5 \%$ milk in TBST. Antibodies against PMCA1 (AbCam, Cambridge, MA, USA; catalog \#ab190355), PMCA2 (ab3529), PMCA3 (ab3530), PMCA4 (ab2783), NCKX3 (St. John's Laboratory, London, UK, catalog \#STJ94358), GAPDH (Santa Cruz Biotechnology, Santa Cruz, CA, USA, catalog \#sc-32233), amelogenin (ThermoFisher Scientific, catalog \#PA5-31286), and cardiac muscle actin (ACTC1) (GeneTex Inc., Irvine, CA, catalog \#GTX101876) were used at dilutions of 1:500, 1:2,000,1:300, 1:5,000, 1:500, 1:500, $1: 3,000$, and $1: 500$, respectively in $5 \%$ milk in TBST. Secondary antibody for PMCA1-4 from Cell Signaling (Danvers, MA, USA; catalog \#7074 and \#7076) was applied at a dilution of 1:10,000. Secondary antibodies for NCKX3, amelogenin, and ACTC1 from Santa Cruz Biotechnology (Santa Cruz, CA, USA; catalog \#sc-2004 and sc-2418) were applied at a dilution of 1:7500. Pierce ECL Plus Western Blotting Substrate (Thermo Scientific, Rockford, IL, USA; catalog \#32132) was used as the detection system for all antibodies. TBST (tris-buffered saline with.1\% Tween-20) was used as a wash buffer. 


\section{Immunofluorescence}

Mandibular incisors were dissected from 9-day-old wild type mice and placed in $4 \%$ paraformaldehyde in PBS overnight. Mouse incisors were preferred to rat incisors in the immunofluorescence studies because mouse incisors decalcify more rapidly and all stages of amelogenesis are visible in one sagittal section. The incisors were then washed in PBS and decalcified in 10\% EDTA in PBS pH 7.4 for 4 weeks at $4^{\circ} \mathrm{C}$. The sample was embedded in paraffin and $4 \mu \mathrm{m}$ sections were cut with a microtome. The sections were deparaffinized and rehydrated. The primary antibodies for PMCA1 and PMCA4 (AbCam, Cambridge, MA, USA; catalog \#ab3528 and \#ab2783, respectively) were used at dilutions of 1:40 and 1:200 in 1\% BSA in PBS, respectively. The primary antibody for NCKX3 (Santa Cruz Biotechnology, Santa Cruz, CA, USA; catalog \#sc-50129) was used at a dilution of 1:50. The secondary antibodies (Vector Laboratories, Burlingame, CA, catalog \#DI-1088, DI-2488, DI2594, DI-3094) were used at a dilution of $1: 300$ in $1 \%$ BSA in PBST. Sections were mounted with mounting medium with DAPI (Vector Laboratories, Burlingame, CA, catalog \#H-1200) and imaged on a Leica TCS SP8 confocal microscope (Leica Biosystems). PBST (0.1\% Tween-20) was used as a wash buffer for the experiments. Negative control sections, using secondary antibody only, under identical conditions, were included and showed negligible auto fluorescence-see Supplemental Figure 1.

\section{RESULTS}

\section{Messenger RNA Expression Profiles}

Quantitative PCR (qPCR) comparing mRNA expression levels in secretory and maturation enamel organ cells for all PMCA (Atp2b), NCX (Slc8) and NCKX (Slc24) gene family members indicate that: (1) PMCA1 (Atp2b1), 3 (Atp2b3), and 4 (Atp2b4), and NCKX3 (Slc24a3) expression is highest during secretory-stage amelogenesis; (2) NCX1 (Slc8a1) and 3 (Slc8a3), and NCKX6 (Slc24a6) were expressed during secretory and maturation stages; and (3) NCKX4 (Slc24a4) is most highly expressed during maturation-stage amelogenesis (Figure 1). The expression levels of PMCA2 (Atp2b2), NCX2 (Slc8a2), NCKX1

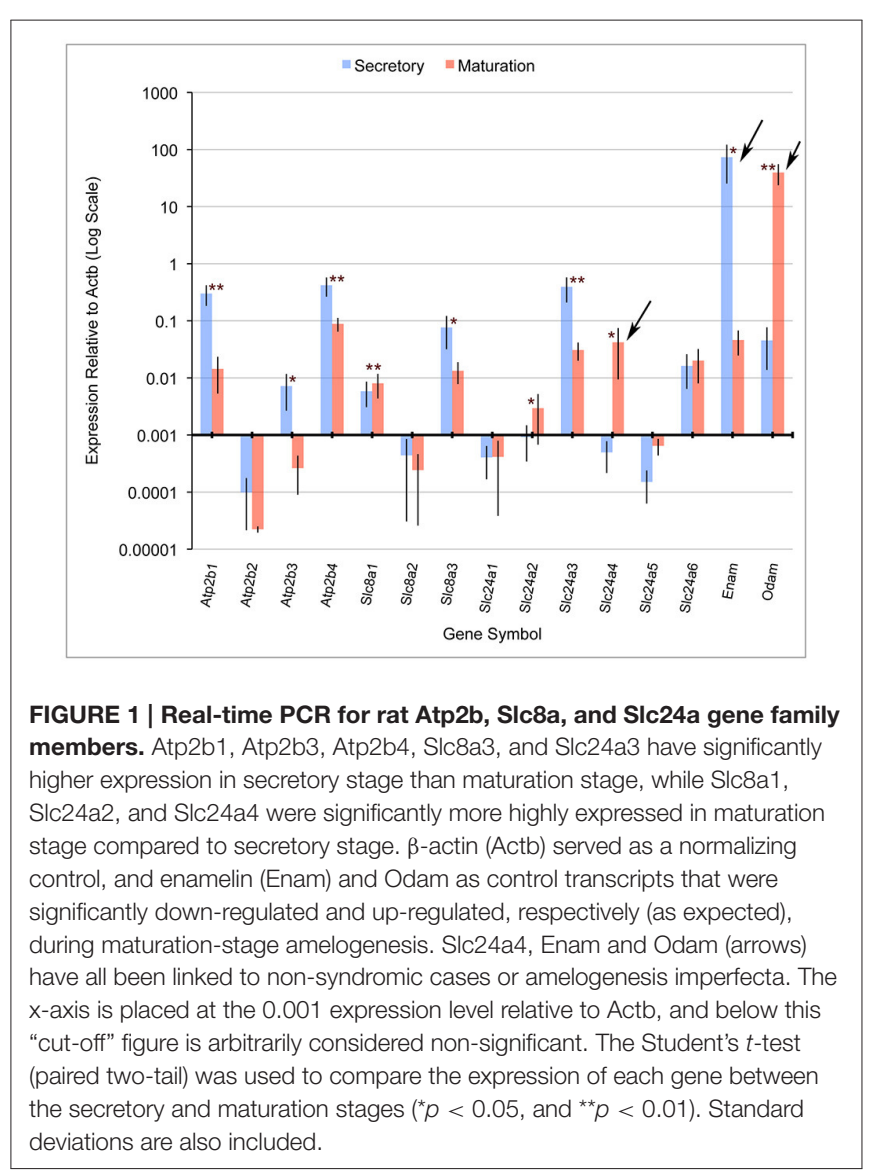

TABLE 2 | Primers used for real-time PCR.

\begin{tabular}{llccll}
\hline Symbol & Accession & Size & Region & Forward & Reverse \\
\hline Atp2b1 & NM_053311 & 219 & $1,387-1,605$ & AAAGCAGGTCTGCTGATGTC & GACGGAGTAAGCCAGTGAGA \\
Atp2b2 & NM_012508 & 168 & $4,129-4,296$ & GAGACGTCGCTTAGCTGAG & AAAGGGTCTGTGTGTGGAAA \\
Atp2b3 & NM_133288 & 207 & $4,073-4,279$ & GCTCCATGACGTAACCAATC & GCGGAATATTGTGGGTGTAG \\
Atp2b4 & NM_001005871 & 184 & $3,698-3,881$ & AATCCAAGAACCAGGTCTCC & ACGGCATTGTTATTCGTGTT \\
Slc8a1 & NM_019268 & 150 & $2,430-2,579$ & CCTGCTTCATTGTCTCCATC & CAAATGTGTCTGGCACTGAG \\
Slc8a2 & NM_078619 & 166 & $377-542$ & AAACGGTGTCCAACCTTACA & ACACACACAGCAATGACCAC \\
Slc8a3 & NM_078620 & 206 & $4,310-4,515$ & TGGTGGAAGCCATCTATGT & AATATGGCCCACTCCCTTAG \\
Slc24a1 & NM_004727 & 155 & $3,238-3,392$ & TTCCTGACCTCATCACCAGT & TGGAACTGGCTGTAATCCAT \\
Slc24a2 & NM_031743 & 214 & $1,280-1,493$ & GGGAGGTTCAGAGAAAAAC & CGATGCTGTGAGAGAGGTT \\
Slc24a3 & NM_053505 & 150 & $2,941-3,090$ & TGACATGTGCTCTTGTTGCT & AATTGGGACTTCATTGACGA \\
Slc24a4 & NM_001108051 & 235 & $401-635$ & AAAGTTGATGGCACCGATAA & AGGGATGGGACAAAGAAGTC \\
Slc24a5 & NM_001107769 & 161 & $371-531$ & AACATGGTTCAACGCTCTC & 58 \\
Slc24a6 & NM_001017488 & 160 & $613-772$ & TTCTCAGACCCTCGTACTGC & ACACGGCCACCATATAGAAA \\
Enam & NM_001106001 & 169 & $1,139-1,307$ & ATGCTGGGAACAATCCTACA & GTGGTTGCCATTGTCTTC \\
Odam & NM_001044274 & 206 & $658-863$ & TTGACAGCTTGTAGGCACA & GACCTCTGTCTGGAAGCAG \\
Actb & NM_031144 & 272 & $559-830$ & CACACTGTGCCCATCTATGA & CCGATAGTGATGACCTGACC
\end{tabular}


(Slc24a1), NCKX2 (Slc24a2), and NCKX5 (Slc24a5) are negligible throughout amelogenesis (Figure 1). These data for NCX (Slc8) and NCKX (Slc24) gene family members are consistant with previously published gene expression data (Okumura et al., 2010; Hu et al., 2012), and add novel information suggesting that PMCA1, PMCA4, and to a lesser extent PMCA3 (which is expressed in secretory enamel organ cells at a level an order of magnitude lower than seen for PMCA1 and PMCA4), play an important role in secretory-stage amelogenesis.

\section{Western Blot Analysis Confirms Expression of PMCA Proteins in Enamel Organ Cells}

Western blot data indicate that PMCA1 and PMCA4 are more highly expressed in secretory stage than in maturation stage, and PMCA2 is not expressed at any appreciable level in amelogenesis, consistent with the qPCR data (Figures 2Ai,Aiv,Aii respectively). Contrary to the qPCR data, PMCA3 and NCKX3 appear to be expressed at similar levels during both secretory stage and maturation stage (Figures 2Aiii,B respectively). Rat brain and heart protein samples were used as control tissues and analyzed with the secretory- and maturation-stage protein samples. The expected molecular weights for PMCA1-4 are $\sim 130,133,123$, and $129 \mathrm{kDa}$ respectively, and relate to the single bands seen at approximately the $150 \mathrm{kDa}$ molecular weight mark (as indicated by an arrow, Figure 2A). The expected molecular weight of NCKX3 is $\sim 60 \mathrm{kDa}$ (Figure 2B). Gapdh has been included as a loading control for all samples, and additional controls include Western analysis for both amelogenin (Amelx) and cardiac muscle alpha actin (Actc) (Figure 2B).

\section{PMCA1 and PMCA4 Localization by Immunofluorescence}

In the enamel organ, PMCA1 expression is seen primarily on the basolateral membrane of both secretory- and maturationstage ameloblasts, with stronger signals seen in secretory ameloblasts (green; Figures 3A-C). These data complement both the qPCR (Figure 1) and Western blot data (Figure 2) on the spatiotemporal expression of PMCA1 in enamel organ cells. When compared to ameloblasts, a weaker signal of PMCA1 is seen in the stratum intermedium (Figure 3A) and papillary layer cells of the enamel organ (Figure 3B); as reflected by the orange color observed in the merged images (Figures 3G-I). In the enamel organ, PMCA4 expression is also seen on the basolateral membrane of secretory- and maturation-stage ameloblasts, and also cells of the stratum intermedium and papillary layer cells (red; Figures 3D-F). Similar to the PMCA1 data, these PMCA4 immunolocalization data complement the $\mathrm{qPCR}$ and Western blot data (Figures 1, 2). The co-localization of both PMCA1 and PMCA4 in polarized ameloblasts can be appreciated in the merged image (yellow; Figures 3G-I), while PMCA4 (but not PMCA1) is also expressed in the stratum intermedium and papillary layer cells of the enamel organ (red; Figures 3G-I).

\section{NCKX3 Localization by Immunofluorescence}

NCKX3 expression is highest in the Tomes' processes (Figure 3M) and the apical membrane of transition- and maturation-stage ameloblasts (Figures 3N,O), while some minor ameloblast-specific intracellular granular immune-reaction is also apparent (Figures 3M-O). We compared the expression
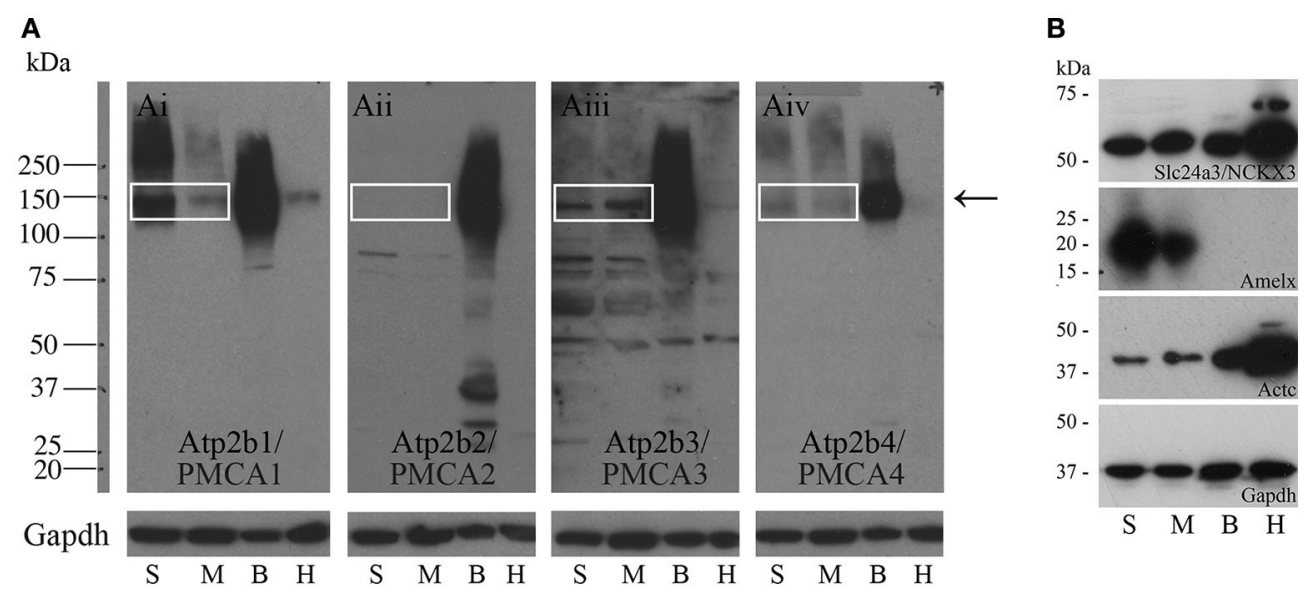

FIGURE 2 | Western blot analyses of PMCA1-4, and NCKX3 in secretory-stage and maturation-stage rat enamel organs. (A) Western blot analysis for PMCA1 (Ai), PMCA2 (Aii), PMCA3 (Aiii) and PMCA4 (Aiv). Samples are secretory-stage enamel organ cells (S), maturation-stage enamel organ cells (M), brain tissue (B) and heart tissue $(\mathrm{H})$. Brain and heart samples are shown for comparison, as all PMCAs are highly expressed in brain and at lower levels in the heart (Brini and Carafoli, 2011; Brini et al., 2017). Molecular weight markers are indicated at left. The expected molecular weights for PMCA1, PMCA2, PMCA3, and PMCA4 are $\sim 130,133,123$, and 129 kDa, respectively. The bands are seen for PMCA1, PMCA3, and PMCA4 (boxed and arrow). No expression of PMCA2 is evident. GAPDH is used here as a loading control. (B) Western blot analysis of NCKX3. The expected molecular weight for NCKX3 is $\sim 60$ kDa. NCKX3 is expressed in all 4 tissue samples tested, with similar expression noted in both secretory-stage and maturation-stage enamel organ cells, and brain tissue. Relatively higher levels of NCKX3 expression can be appreciated in heart tissue. Amelx and Actc are used as controls as expression is highest in secretory-stage ameloblasts (Lacruz et al., 2012a,b) and heart tissue (Hamada et al., 1982) respectively. GAPDH is used here as a loading control. 

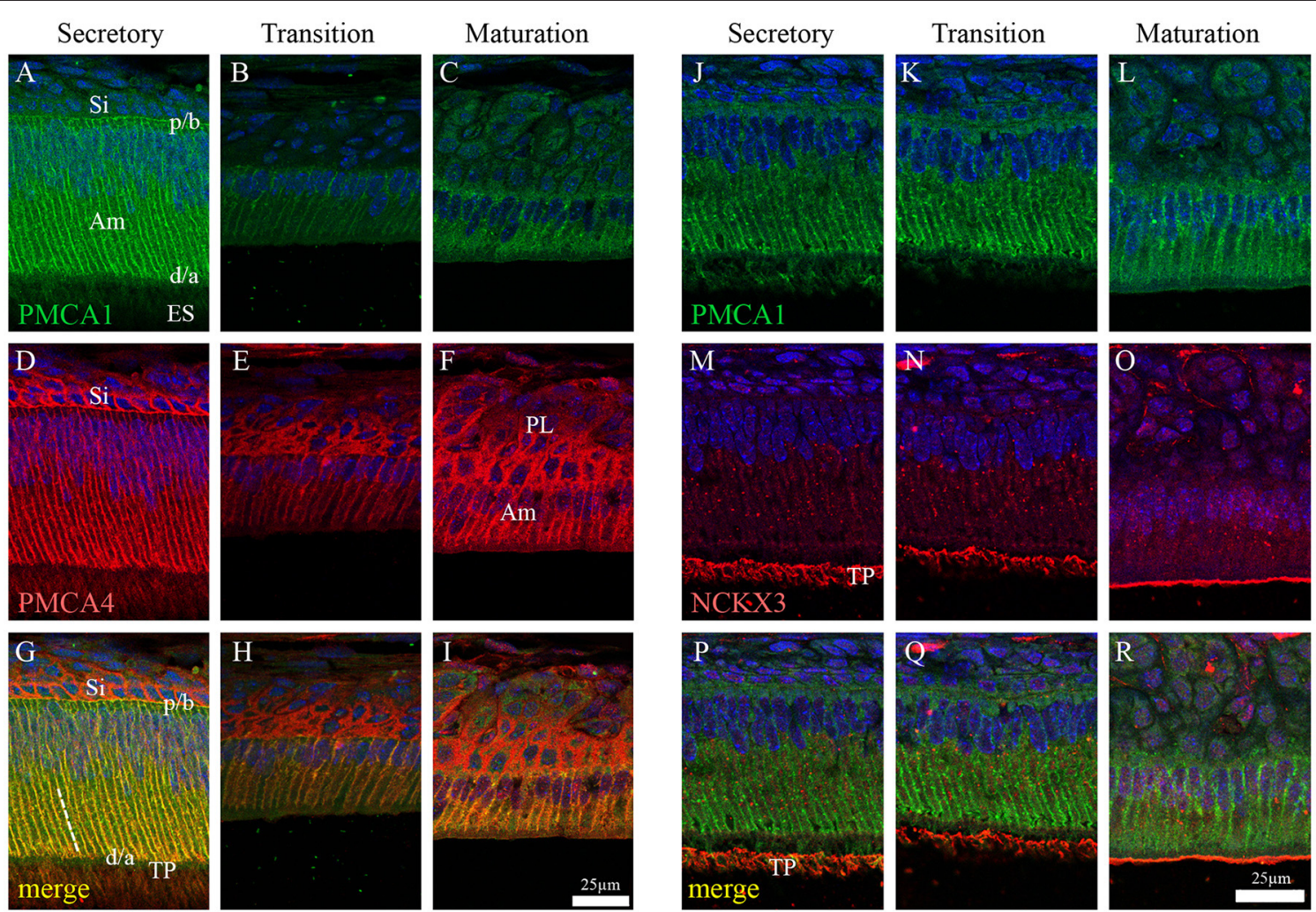

FIGURE 3 | Immunofluorescence analysis of PMCA1, PMCA4, and NCKX3 in 9-day-old mouse mandibular incisors. Columns from left to right show secretory-stage (A,D,G,J,M,P), transition-stage (B,E,H,K,N,Q) and maturation-stage (C,F,I,L,O,R) ameloblasts; while rows show immunoreactivity for PMCA1 (green; A-C and J-L), PMCA4 (red; D-F) and NCKX3 (red; M-O). Merged images are also shown for each column (A,D merged to G; B,E merged to H; $\mathbf{C , F}$ merged to I; J,M merged to $\mathbf{P} ; \mathbf{K}, \mathbf{N}$ merged to $\mathbf{Q}$; and $\mathbf{L}$ and $\mathbf{O}$ merged to $\mathbf{R}$ ). Am, Ameloblasts; ES, enamel space; Si, stratum intermediu (TP; secretory ameloblasts only), Tomes' processes and (PL, maturation ameloblasts only), papillary layer. The proximal/basal poles (p/b) and distal/apical poles (d/a) of ameloblast cells are identified, as are the lateral membranes of ameloblasts (broken while line in $\mathbf{G}$ ). Scale for (A-I) shown in (I); and scale for (J-R) shown in $\mathbf{R}$.

profile for NCKX3 (red; Figures 3M-O) to the expression profile of the control PMCA1 (green; Figures 3J-L). As can be appreciated from the images (Figures $3 \mathbf{M}-\mathbf{R}$ ), the expression profile for $\mathrm{NCKX} 3$ in the enamel organ is highest at the distal/apical pole, and this is distinct from the expression profiles seen for PMCA1 and PMCA4 where expression is seen on the lateral membranes of polarized ameloblasts (for both PMCA1 and PMCA4) and stratum intermedium and papillary layer cells (only PMCA4) (Figures 3A-L).

\section{DISCUSSION}

From data presented here and prior studies, it is possible to make the following generalizations. First, of the four unique genes coding the PMCAs, PMCA1, and PMCA4 are highly expressed on the basolateral membranes of polarized ameloblasts; and both are expressed during secretory- and maturationstage amelogenesis. These data somewhat contradicts previously published data suggesting PMCA1 and PMCA4 are localized primarily to Tomes' processes of secretory ameloblasts (Sasaki and Garant, 1986c; Borke et al., 1995). These differences likely result from the different specificities of antibodies used to carry out these studies, and as noted previously, protein localization differences may also result from the different chemical and processing techniques used by the various laboratories (Takano, 1995). While expression of PMCA1 is primarily in the basolateral membrane of ameloblasts, there are also lower expression levels noted in the cells of stratum intermedium and papillary layer. Similarly, while expression of PMCA4 is seen in the basolateral membrane of ameloblasts, expression of PMCA4 is also recognized as a feature of the cells of the stratum intermedium and papillary layer cells. Of the three unique genes coding for the NCXs, NCX1, and NCX3 are highly expressed at the apical pole of both secretory- and maturation-stage ameloblasts (Okumura et al., 2010). Finally, of the six unique genes coding for NCKXs, NCKX3 (data reported here; Figures 1-3) and NCKX4 (Hu et al., 2012; Wang et al., 2014) are both highly expressed at the apical pole of polarized ameloblasts. A similar level of expression of NCKX3 is noted in both secretory- and maturationstage ameloblasts (Figures 2, 3). While expression of NCKX4 is negligible in secretory-stage ameloblasts, it is highly expressed in maturation-stage ameloblasts (Hu et al., 2012; Wang et al., 2014). All six proteins expressed in ameloblasts (PMCA1, PMCA4, NCX1, NCX3, NCKX3, and NCKX4) export $\mathrm{Ca}^{2+}$ from the 

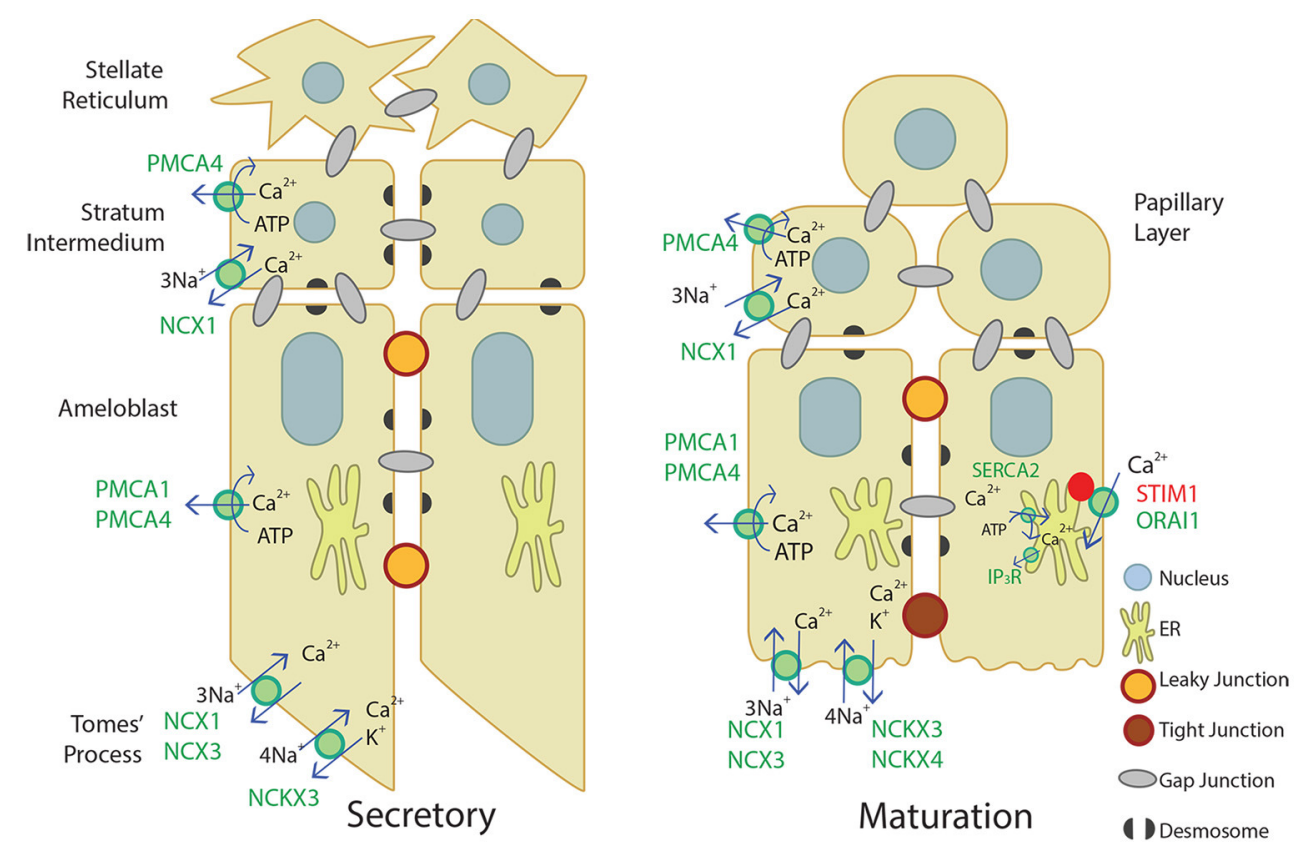

FIGURE 4 | Schematic of what is currently proposed for secretory- and maturation-stage transcellular calcium transport in amelogenesis. During the secretory-stage (left image), active $\mathrm{Ca}^{2+}$ transport on the lateral membrane is primarily mediated by PMCA1 and PMCA4 and ATP is hydrolyzed in the process. NCX1, NCX3, and NCKX3 mediate $\mathrm{Ca}^{2+}$ export in the Tomes' process. More calcium transporters are expressed during the maturation stage (right image). The CRAC channel, composed of the channel ORAl1 and the ER membrane calcium sensor STIM1, mediates the bulk of calcium entry and is active in response to ER calcium store depletion through $\mathrm{IP}_{3} \mathrm{R}$. The cell then removes calcium from the cytoplasm through the SERCA2 pump that replenishes ER stores, and the NCKX and NCX proteins on the apical border plasma membrane that export calcium into the enamel area and facilitate mineralization (Nurbaeva et al., 2015a,b, 2017). NCX1 and PMCA4 export $\mathrm{Ca}^{2+}$ from the stratum intermedium (secretory-stage enamel organ) and papillary layer (maturation-stage enamel organ). Desmosomes (Sasaki et al., 1984; Fausser et al., 1998; Jheon et al., 2011) and gap junctions (Sasaki and Garant, 1986a,b,d; Pinero et al., 1994; Inai et al., 1997) have also been identified bridging or uniting adjacent epithelial cells in the enamel organ, and are also illustrated.

cytoplasm to the extracellular space, thus ameloblasts may be one of the more complicated epithelial cell types when it comes to understanding ion movements related to $\mathrm{Ca}^{2+}$ transport as they relate to a mineralizing dental enamel.

The data suggest that there are likely redundancies amongst similarly functioning proteins from these gene families. For example, from this list of six $\mathrm{Ca}^{2+}$ export proteins expressed in ameloblasts, only mutations to SLC24A4/NCKX4 have been linked to enamel pathologies (Parry et al., 2013; Seymen et al., 2014; Wang et al., 2014; Herzog et al., 2015). NCKX4 exports $\mathrm{Ca}^{2+}$ from the apical pole of maturation-stage ameloblasts at the developmental stage where enamel mineralization is at its greatest; thus, NCKX4 may play a greater role in enamel formation than either NCX1 or NCX3, which have expression localized to the apical pole throughout the entire process of amelogenesis. It is conceivable that if the function of either NCX1 or NCX3 is less than optimal, the other may compensate such that no overt enamel phenotype results. Future studies may be able to address whether NCX1 and NCX3 are equivalent in enamel formation.

Similar to NCX1 and NCX3 in ameloblasts, PMCA1 and PMCA4 or other calcium handling proteins may be able to overcome the effects of Atp2b1 or Atp2b4 mutations, or gene silencing. No human pathologies have yet been linked to ATP2B1 mutations (as noted in the Online Mendelian Inheritance in Man; http://omim.org/entry/108731), however Atp2b1-null mice are embryonic lethal (Okunade et al., 2004). Only recently a case of familial spastic paraplegia has been linked to an ATP2B4 mutation (Ho et al., 2015; http://omim.org/entry/108732), and while Atp2b4-null mice have no overt phenotype, the male mice are infertile due to reduced sperm motility (Okunade et al., 2004; Schuh et al., 2004; Kim et al., 2012). The similar expression profiles of PMCA1 and PMCA4 in ameloblasts (that being to the basolateral membrane) may suggest that loss of PMCA4 function in ameloblasts may be compensated by PMCA1, while the loss of PMCA1 function remains embryonic lethal. If this is correct, studying PMCA1 activities in in vivo enamel formation would, in the future, be limited to conditional knockout or heterozygote animal models. The localization of PMCA1 and PMCA4 on the ameloblast basolateral membrane may suggest that these $\mathrm{Ca}^{2+}$ pumps are unlikely to have a critical role in enamel mineralization; i.e., $\mathrm{Ca}^{2+}$ removed by the PMCA pumps may not directly be incorporated into the Hap mineral phase. Instead, the PMCA pumps may be indirectly involved in amelogenesis by maintaining ameloblast $\mathrm{Ca}^{2+}$ homeostasis; or being a part of ameloblast cell signaling pathways. As calcium is transported through the stratum intermedium and papillary layer to the ameloblasts and the enamel organ, the PMCA 
TABLE 3 | Major and most highly expressed calcium export pumps and exchangers in enamel organ cells.

\begin{tabular}{|c|c|c|c|c|c|c|}
\hline Gene/protein & $\begin{array}{l}\text { Secretory } \\
\text { ameloblasts }\end{array}$ & $\begin{array}{l}\text { Stratum } \\
\text { intermedium }\end{array}$ & $\begin{array}{l}\text { Stellate } \\
\text { reticulum }\end{array}$ & $\begin{array}{l}\text { Maturation } \\
\text { ameloblasts }\end{array}$ & Papillary layer cells & References \\
\hline Atp2b1/PMCA1 & Basolateral & $\boldsymbol{V}$ (weak) & $x$ & Basolateral & $\boldsymbol{V}$ (Weak) & \\
\hline Atp2b4/PMCA4 & Basolateral & $\checkmark$ & $x$ & Basolateral & $\checkmark$ & \\
\hline Slc8a1/NCX1 & Apical & $\checkmark$ & $x$ & Apical & $\checkmark$ & Okumura et al., 2010 \\
\hline Slc8a3/NCX3 & Apical & $x$ & $x$ & Apical & $x$ & Okumura et al., 2010 \\
\hline Slc24a3/NCKX3 & Apical & $x$ & $x$ & Apical & $x$ & \\
\hline Slc24a4/NCKX4 & $x$ & $x$ & $x$ & Apical & $x$ & Hu et al., 2012; Wang et al., 2014 \\
\hline
\end{tabular}

family may additionally be valuable in shuttling the calcium from circulation to the ameloblasts. The PMCA family can be involved in $\mathrm{IP}_{3}$-mediated calcium signaling (Penniston et al., 2014), and PMCA1 and PMCA4 are involved in RANKL signaling and regulate osteoclast differentiation (Kim et al., 2012). In cultured osteoclasts, the knockdown and/or silencing of both PMCA1 and PMCA4 increased protein expression of SERCA2 and TRPV5 (Kim et al., 2012). Indeed, the PMCA transporters may have evolved to fine-tune intracellular calcium concentration as they have higher calcium affinity and lower capability for bulk $\mathrm{Ca}^{2+}$ transport than the NCX/NCKX exchangers (Brini and Carafoli, 2011), and are therefore more likely to play a housekeeping role by removal of intracelullar $\mathrm{Ca}^{2+}$ during maturation stage enamel mineralization which may also prevent calcium overload and possibly ameloblasts apoptosis. The PMCA transporters have multiple known expressed isoforms in other tissues but this has not yet been studied in the enamel organ.

Our novel data adds to the current understanding of $\mathrm{Ca}^{2+}$ transport in secretory and maturation stage enamel organ, described in Figure 4. $\mathrm{Ca}^{2+}$ import by the CRAC channel, ER $\mathrm{Ca}^{2+}$ export by $\mathrm{IP}_{3} \mathrm{R}$, and $\mathrm{ER} \mathrm{Ca}^{2+}$ import by the SERCA2 pump have been well-described elsewhere (Nurbaeva et al., 2015a,b, 2017). In summary, when $\mathrm{Ca}^{2+}$ is released from the ER through $\mathrm{IP}_{3} \mathrm{R}$, STIM1 associates with ORAI1 and forms the CRAC channel that allows $\mathrm{Ca}^{2+}$ to flow into the cell. $\mathrm{Ca}^{2+}$ is then removed from the cytoplasm through PMCA1 and PMCA4 on the basal and lateral membranes, NCX1, NCX3, NCKX3, and NCKX4 on the apical membrane, and SERCA2 on the ER membrane. NCX1 and PMCA4 are also involved in $\mathrm{Ca}^{2+}$ export in the stratum intermedium and papillary layer. This process of $\mathrm{Ca}^{2+}$ cycling occurs more during the maturation stage, when large amounts of $\mathrm{Ca}^{2+}$ are necessary for enamel mineralization. During the secretory stage, PMCA1, PMCA4, NCX1, NCX3, and NCKX3 are the known $\mathrm{Ca}^{2+}$ exporters expressed, but further studies are necessary to understand $\mathrm{Ca}^{2+}$ import and other mechanisms of $\mathrm{Ca}^{2+}$ export during enamel secretion.

\section{CONCLUSION}

Based on the available data, we have reviewed and summarized the expression profiles of the major $\mathrm{Ca}^{2+}$ export pumps and exchangers in enamel organ cells (Table 3; Okumura et al., 2010; Hu et al., 2012; Wang et al., 2014), and illustrated these $\mathrm{Ca}^{2+}$ export proteins along with the current model for $\mathrm{Ca}^{2+}$ import in enamel organ cells as proposed by Nurbaeva et al. (2015a,b, 2017) (Figure 4). As future studies continue to better define $\mathrm{Ca}^{2+}$ export (and also $\mathrm{Ca}^{2+}$ import-see Nurbaeva et al., 2015a,b, 2017) during amelogenesis, the information in Table 3 will undoubtedly expand and become more precisely defined. Ultimately, elucidating the multitude of mechanisms involved in transcellular $\mathrm{Ca}^{2+}$ movements in the enamel-forming cells will result in a better understanding of the physiology and formation of enamel, the hardest and most calcified tissue in mammals.

\section{AUTHOR CONTRIBUTIONS}

SR, XW, CS, and MP designed the experiments and wrote the manuscript; $S R$ and $\mathrm{XW}$ performed the experiments; SR, XW, KY, JC, CS, and MP analyzed the data; SR, XW, and MP prepared the figures and tables; All listed authors critically read, edited, and approved the final manuscript. MP accepts full responsibility for the integrity of the data analysis.

\section{ACKNOWLEDGMENTS}

The authors would like to thank Bridget Samuels for her help in the preparation of this manuscript, and Dr. Rodrigo S. Lacruz for his helpful comments and edits of the final version. This work was supported by grants DE019629 (MP), DE021982 (SR), and DE022528 (KY) from the National Institute of Dental and Craniofacial Research/National Institutes of Health. The authors declare no potential conflicts of interest with respect to the authorship and/or publication of this article.

\section{SUPPLEMENTARY MATERIAL}

The Supplementary Material for this article can be found online at: http://journal.frontiersin.org/article/10.3389/fphys. 2017.00336/full\#supplementary-material 


\section{REFERENCES}

Arquitt, C. K., Boyd, C., and Wright, J. T. (2002). Cystic fibrosis transmembrane regulator gene (CFTR) is associated with abnormal enamel formation. J. Dent. Res. 81, 492-496. doi: 10.1177/154405910208100712

Berridge, M. J., Bootman, M. D., and Roderick, H. L. (2003). Calcium signalling: dynamics, homeostasis and remodelling. Nat. Rev. Mol. Cell Biol. 4, 517-529. doi: $10.1038 / \mathrm{nrm} 1155$

Bertini, E., Des Portes, V., Zanni, G., Santorelli, F., Dionisi-Vici, C., Vicari, S., et al. (2000). X-linked congenital ataxia: a clinical and genetic study. Am. J. Med. Genet. 92, 53-56. doi: 10.1002/(SICI)1096-8628(20000501)92:1<53::AIDAJMG9>3.0.CO;2-F

Blair, H. C., Robinson, L. J., Huang, C. L., Sun, L., Friedman, P. A., Schlesinger, P. H., et al. (2011). Calcium and bone disease. Biofactors 37, 159-167. doi: 10.1002/biof.143

Borke, J. L., Zaki, A. E.-M., Eisenmann, D. R., and Mednieks, M. I. (1995). Localization of plasma membrane $\mathrm{Ca}^{2+}$ pump mRNA and protein in human ameloblasts by in situ hybridization and immunohistochemistry. Connect. Tissue Res. 33, 139-144. doi: 10.3109/03008209509016993

Bortolozzi, M., Brini, M., Parkinson, N., Crispino, G., Scimemi, P., De Siati, R. D., et al. (2010). The novel PMCA2 pump mutation Tommy impairs cytosolic calcium clearance in hair cells and links to deafness in mice. J. Biol. Chem. 285, 37693-37703. doi: 10.1074/jbc.M110.170092

Brini, M. (2009). Plasma membrane $\mathrm{Ca}^{2+}$-ATPase: from a housekeeping function to a versatile signaling role. Pflugers Arch. 257, 657-664. doi: 10.1007/s00424-008-0505-6

Brini, M., Cali, T., Ottolini, D., and Carafoli, E. (2013). The plasma membrane calcium pump in health and disease. FEBS J. 280, 5385-5397. doi: $10.1111 /$ febs. 12193

Brini, M., and Carafoli, E. (2011). The plasma membrane $\mathrm{Ca}^{2+}$ ATPase and the plasma membrane sodium calcium exchanger cooperate in the regulation of cell calcium. Cold Spring Harb. Perspect. Biol. 3:a004168. doi: $10.1101 /$ cshperspect.a004168

Brini, M., Carafoli, E., and Cali, T. (2017). The plasma membrane calcium pumps: focus on the role in (neuro)pathology. Biochem. Biophys. Res. Commun. 483, 1116-1124. doi: 10.1016/j.bbrc.2016.07.117

Bronckers, A., Kalogeraki, L., Jorna, H. J., Wilke, M., Bervoets, T. J., Lyaruu, D. M., et al. (2010). The cystic fibrosis transmembrane conductance regulator (CFTR) is expressed in maturation stage ameloblasts, odontoblasts and bone cells. Bone 46, 1188-1196. doi: 10.1016/j.bone.2009.12.002

Bronckers, A. L., Lyaruu, D., Jalali, R., Medina, J. F., Zandieh-Doulabi, B., and Denbesten, P. K. (2015). Ameloblast modulation and transport of $\mathrm{Cl}^{-}, \mathrm{Na}^{+}$, and $\mathrm{K}^{+}$during Amelogenesis. J. Dent. Res. 94, 1740-1747. doi: $10.1177 / 0022034515606900$

Cai, X., and Lytton, J. (2004). Molecular cloning of a sixth member of the $\mathrm{K}^{+}$dependent $\mathrm{Na}^{+} / \mathrm{Ca}^{2+}$ exchanger gene family, NCKX6. J. Biol. Chem. 279, 5867-5876. doi: 10.1074/jbc.M310908200

Curry, M. C., Luk, N. A., Kenny, P. A., Roberts-Thomson, S. J., and Monteith, G. R. (2012). Distinct regulation of cytoplasmic calcium signals and cell death pathways by different plasma membrane calcium ATPase isoforms in MDA-MB-231 breast cancer cells. J. Biol. Chem. 287, 28598-28608. doi: 10.1074/jbc.M112.364737

Curry, M. C., Roberts-Thomson, S. J., and Monteith, G. R. (2011). Plasma membrane calcium ATPases and cancer. Biofactors 37, 132-138. doi: 10.1002/biof.146

Fausser, J. L., Schlepp, O., Aberdam, D., Meneguzzi, G., Ruch, J. V., and Lesot, H. (1998). Localization of antigens associated with adherens junctions, desmosomes, and hemidesmosomes during murine molar morphogenesis. Differentiation 63, 1-11. doi: 10.1046/j.1432-0436.1998.6310001.x

Giacomello, M., De Mario, A., Scarlatti, C., Primerano, S., and Carafoli, E. (2013). Plasma membrane calcium ATPases and related disorders. Int. J. Biochem. Cell Biol. 45, 753-762. doi: 10.1016/j.biocel.2012.09.016

Hamada, H., Petrino, M. G., and Kakunaga, T. (1982). Molecular structure and evolutionary origin of human cardiac muscle actin gene. Proc. Natl. Acad. Sci. U.S.A. 79, 5901-5905. doi: 10.1073/pnas.79.19.5901

Herzog, C. R., Reid, B. M., Seymen, F., Koruyucu, M., Tuna, E. B., Simmer, J. P., et al. (2015). Hypomaturation amelogenesis imperfecta caused by a novel SLC24A4 mutation. Oral Surg. Oral Med. Oral Pathol. Oral Radiol. 119, e77-e81. doi: 10.1016/j.0ooo.2014.09.003

Ho, P. W., Pang, S. Y., Li, M., Tse, Z. H., Kung, M. H., Sham, P. C., et al. (2015). PMCA4 (ATP2B4) mutation in familial spastic paraplegia causes delay in intracellular calcium extrusion. Brain Behav. 5:e00321. doi: 10.1002/brb3.321

Hu, J. C., Chun, Y. H., Al Hazzazzi, T., and Simmer, J. P. (2007). Enamel formation and amelogenesis imperfecta. Cells Tissues Organs 186, 78-85. doi: $10.1159 / 000102683$

Hu, P., Lacruz, R. S., Smith, C. E., Smith, S. M., Kurtz, I., and Paine, M. L. (2012). Expression of the sodium/calcium/potassium exchanger, NCKX4, in ameloblasts. Cells Tissues Organs 196, 501-509. doi: 10.1159/000337493

Hubbard, M. J. (1996). Articular debridement versus washout for degeneration of the medial femoral condyle. A five-year study. J. Bone Joint Surg. Br. 78, 217-219.

Hubbard, M. J. (2000). Calcium transport across the dental enamel epithelium. Crit. Rev. Oral Biol. Med. 11, 437-466. doi: 10.1177/10454411000110040401

Inai, T., Nakamura, K., Kurisu, K., and Shibata, Y. (1997). Immunohistochemical localization of connexin43 in the enamel organ of the rat upper incisor during ameloblast development. Arch. Histol. Cytol. 60, 297-306. doi: $10.1679 /$ aohc.60.297

Jalloul, A. H., Rogasevskaia, T. P., Szerencsei, R. T., and Schnetkamp, P. P. (2016a). A functional study of mutations in $\mathrm{K}^{+}$-dependent $\mathrm{Na}^{+}-\mathrm{Ca}^{2+}$ exchangers associated with amelogenesis imperfecta and non-syndromic Oculocutaneous Albinism. J. Biol. Chem. 291, 13113-13123. doi: 10.1074/jbc.M116.728824

Jalloul, A. H., Szerencsei, R. T., and Schnetkamp, P. P. (2016b). Cation dependencies and turnover rates of the human $\mathrm{K}^{+}$-dependent $\mathrm{Na}^{+}-\mathrm{Ca}^{2}$ exchangers NCKX1, NCKX2, NCKX3 and NCKX4. Cell Calcium 59, 1-11. doi: 10.1016/j.ceca.2015.11.001

Jheon, A. H., Mostowfi, P., Snead, M. L., Ihrie, R. A., Sone, E., Pramparo, T., et al. (2011). PERP regulates enamel formation via effects on cell-cell adhesion and gene expression. J. Cell Sci. 124, 745-754. doi: 10.1242/jcs.078071

Josephsen, K., Takano, Y., Frische, S., Praetorius, J., Nielsen, S., Aoba, T., et al. (2010). Ion transporters in secretory and cyclically modulating ameloblasts: a new hypothesis for cellular control of preeruptive enamel maturation. Am. J. Physiol. Cell Physiol. 299, C1299-C1307. doi: 10.1152/ajpcell.00218.2010

Khananshvili, D. (2013). The SLC8 gene family of sodium-calcium exchangers (NCX) - structure, function, and regulation in health and disease. Mol. Aspects Med. 34, 220-235. doi: 10.1016/j.mam.2012.07.003

Kim, H. J., Prasad, V., Hyung, S. W., Lee, Z. H., Lee, S. W., Bhargava, A., et al. (2012). Plasma membrane calcium ATPase regulates bone mass by finetuning osteoclast differentiation and survival. J. Cell Biol. 199, 1145-1158. doi: $10.1083 /$ jcb. 201204067

Krebs, J. (2009). The influence of calcium signaling on the regulation of alternative splicing. Biochim. Biophys. Acta 1793, 979-984. doi: 10.1016/j.bbamcr.2008.12.006

Lacruz, R. S., Smith, C. E., Bringasjr, P., Chen, Y. B., Smith, S. M., Snead, M. L., et al. (2012a). Identification of novel candidate genes involved in mineralization of dental enamel by genome-wide transcript profiling. J. Cell. Physiol. 227, 2264-2275. doi: 10.1002/jcp. 22965

Lacruz, R. S., Smith, C. E., Kurtz, I., Hubbard, M. J., and Paine, M. L. (2013). New paradigms on the transport functions of maturation-stage ameloblasts. J. Dent. Res. 92, 122-129. doi: 10.1177/0022034512470954

Lacruz, R. S., Smith, C. E., Moffatt, P., Chang, E. H., Bromage, T. G., Bringas, P. Jr., et al. (2012b). Requirements for ion and solute transport, and $\mathrm{pH}$ regulation during enamel maturation. J. Cell. Physiol. 227, 1776-1785. doi: $10.1002 /$ jcp. 22911

Lee, G. S., Choi, K. C., and Jeung, E. B. (2009). $\mathrm{K}^{+}$-dependent $\mathrm{Na}^{+} / \mathrm{Ca}^{2+}$ exchanger 3 is involved in renal active calcium transport and is differentially expressed in the mouse kidney. Am. J. Physiol. Renal Physiol. 297, F371-F379. doi: 10.1152/ajprenal.90615.2008

Lee, K. H., Ho, W. K., and Lee, S. H. (2013). Endocytosis of somatodendritic NCKX2 is regulated by Src family kinase-dependent tyrosine phosphorylation. Front. Cell. Neurosci. 7:14. doi: 10.3389/fncel.2013.00014

Lyaruu, D. M., Bronckers, A. L., Mulder, L., Mardones, P., Medina, J. F., Kellokumpu, S., et al. (2008). The anion exchanger Ae2 is required for enamel maturation in mouse teeth. Matrix Biol. 27, 119-127. doi: 10.1016/j.matbio.2007.09.006 
Lytton, J. (2007). $\mathrm{Na}^{+} / \mathrm{Ca}^{2+}$ exchangers: three mammalian gene families control $\mathrm{Ca}^{2+}$ transport. Biochem. J. 406, 365-382. doi: 10.1042/BJ20070619

Mondal, M., Sengupta, M., Samanta, S., Sil, A., and Ray, K. (2012). Molecular basis of albinism in India: evaluation of seven potential candidate genes and some new findings. Gene 511, 470-474. doi: 10.1016/j.gene.2012. 09.012

Nurbaeva, M. K., Eckstein, M., Concepcion, A. R., Smith, C. E., Srikanth, S., Paine, M. L., et al. (2015a). Dental enamel cells express functional SOCE channels. Sci. Rep. 5:15803. doi: 10.1038/srep15803

Nurbaeva, M. K., Eckstein, M., Feske, S., and Lacruz, R. S. (2017). Ca ${ }^{2+}$ transport and signalling in enamel cells. J. Physiol. 595, 3015-3039. doi: 10.1113/JP272775

Nurbaeva, M. K., Eckstein, M., Snead, M. L., Feske, S., and Lacruz, R. S. (2015b). Store-operated $\mathrm{Ca}^{2+}$ entry modulates the expression of enamel genes. J. Dent. Res. 94, 1471-1477. doi: 10.1177/0022034515 598144

Okumura, R., Shibukawa, Y., Muramatsu, T., Hashimoto, S., Nakagawa, K., Tazaki, M., et al. (2010). Sodium-calcium exchangers in rat ameloblasts. J. Pharmacol. Sci. 112, 223-230. doi: 10.1254/jphs.09267FP

Okunade, G. W., Miller, M. L., Pyne, G. J., Sutliff, R. L., O'connor, K. T., Neumann, J. C., et al. (2004). Targeted ablation of plasma membrane $\mathrm{Ca}^{2+}$-ATPase (PMCA) 1 and 4 indicates a major housekeeping function for PMCA1 and a critical role in hyperactivated sperm motility and male fertility for PMCA4. J. Biol. Chem. 279, 33742-33750. doi: 10.1074/jbc.M404 628200

Orrenius, S., Gogvadze, V., and Zhivotovsky, B. (2015). Calcium and mitochondria in the regulation of cell death. Biochem. Biophys. Res. Commun. 460, 72-81. doi: 10.1016/j.bbrc.2015.01.137

Paine, M. L., Wang, H. J., Abuladze, N., Liu, W., Wall, S., Kim, Y. H., et al. (2007). "Expression of AE2 and $\mathrm{NBC} 1$ in secretory ameloblasts," in Experimental Biology Annual Meeting (Washington, DC).

Palmgren, M. G., and Nissen, P. (2011). P-type ATPases. Annu. Rev. Biophys. 40, 243-266. doi: 10.1146/annurev.biophys.093008.131331

Parry, D. A., Poulter, J. A., Logan, C. V., Brookes, S. J., Jafri, H., Ferguson, C. H., et al. (2013). Identification of mutations in SLC24A4, encoding a potassiumdependent sodium/calcium exchanger, as a cause of amelogenesis imperfecta. Am. J. Hum. Genet. 92, 307-312. doi: 10.1016/j.ajhg.2013.01.003

Penniston, J. T., Padanyi, R., Paszty, K., Varga, K., Hegedus, L., and Enyedi, A. (2014). Apart from its known function, the plasma membrane $\mathrm{Ca}^{2+}$ ATPase can regulate $\mathrm{Ca}^{2+}$ signaling by controlling phosphatidylinositol 4,5-bisphosphate levels. J. Cell Sci. 127, 72-84. doi: 10.1242/jcs. 132548

Pinero, G. J., Parker, S., Rundus, V., Hertzberg, E. L., and Minkoff, R. (1994). Immunolocalization of connexin 43 in the tooth germ of the neonatal rat. Histochem. J. 26, 765-770. doi: 10.1007/BF02388633

Riazuddin, S. A., Shahzadi, A., Zeitz, C., Ahmed, Z. M., Ayyagari, R., Chavali, V. R., et al. (2010). A mutation in SLC24A1 implicated in autosomal-recessive congenital stationary night blindness. Am. J. Hum. Genet. 87, 523-531. doi: 10.1016/j.ajhg.2010.08.013

Sasaki, T., and Garant, P. R. (1986a). Fate of annular gap junctions in the papillary cells of the enamel organ in the rat incisor. Cell Tissue Res. 246, 523-530. doi: $10.1007 /$ BF00215192

Sasaki, T., and Garant, P. R. (1986b). A study of post-secretory maturation ameloblasts in the cat by transmission and freeze-fracture electronmicroscopy. Arch. Oral Biol. 31, 587-596. doi: 10.1016/0003-9969(86) 90082-8

Sasaki, T., and Garant, P. R. (1986c). Ultracytochemical demonstration of ATPdependent calcium pump in ameloblasts of rat incisor enamel organ. Calcif. Tissue Int. 39, 86-96. doi: 10.1007/BF02553296

Sasaki, T., and Garant, P. R. (1986d). An ultrastructural study of the papillary layer and its vascular bed in the kitten enamel organ. Anat. Rec. 214, 353-364. doi: 10.1002/ar.1092140404

Sasaki, T., Segawa, K., Takiguchi, R., and Higashi, S. (1984). Intercellular junctions in the cells of the human enamel organ as revealed by freeze-fracture. Arch. Oral Biol. 29, 275-286. doi: 10.1016/0003-9969(84)90101-8

Schnetkamp, P. P. (2004). The SLC24 $\mathrm{Na}^{+} / \mathrm{Ca}^{2+}-\mathrm{K}^{+}$exchanger family: vision and beyond. Pflugers Arch. 447, 683-688. doi: 10.1007/s00424-003-1069-0

Schuh, K., Cartwright, E. J., Jankevics, E., Bundschu, K., Liebermann, J., Williams, J. C., et al. (2004). Plasma membrane $\mathrm{Ca}^{2+}$ ATPase 4 is required for sperm motility and male fertility. J. Biol. Chem. 279, 28220-28226. doi: 10.1074/jbc.M312599200

Seymen, F., Lee, K. E., Tran Le, C. G., Yildirim, M., Gencay, K., Lee, Z. H., et al. (2014). Exonal deletion of SLC24A4 causes hypomaturation amelogenesis imperfecta. J. Dent. Res. 93, 366-370. doi: 10.1177/0022034514523786

Sharma, V., and O'halloran, D. M. (2014). Recent structural and functional insights into the family of sodium calcium exchangers. Genesis 52, 93-109. doi: $10.1002 /$ dvg. 22735

Shumilina, E., Xuan, N. T., Matzner, N., Bhandaru, M., Zemtsova, I. M., and Lang, F. (2010). Regulation of calcium signaling in dendritic cells by 1,25 dihydroxyvitamin D3. FASEB J. 24, 1989-1996. doi: 10.1096/fj.09-142265

Skobe, Z. (2006). SEM evidence that one ameloblast secretes one keyholeshaped enamel rod in monkey teeth. Eur. J. Oral Sci. 114, 338-342. doi: 10.1111/j.1600-0722.2006.00305.x

Smith, C. E. (1998). Cellular and chemical events during enamel maturation. Crit. Rev. Oral Biol. Med. 9, 128-161. doi: 10.1177/10454411980090020101

Sokolow, S., Manto, M., Gailly, P., Molgo, J., Vandebrouck, C., Vanderwinden, J. M., et al. (2004). Impaired neuromuscular transmission and skeletal muscle fiber necrosis in mice lacking $\mathrm{Na} / \mathrm{Ca}$ exchanger 3. J. Clin. Invest. 113, 265-273. doi: $10.1172 / J C I 18688$

Stephan, A. B., Tobochnik, S., Dibattista, M., Wall, C. M., Reisert, J., and Zhao, H. (2011). The $\mathrm{Na}^{+} / \mathrm{Ca}^{2+}$ exchanger NCKX4 governs termination and adaptation of the mammalian olfactory response. Nat. Neurosci. 15, 131-137. doi: $10.1038 / \mathrm{nn} .2943$

Street, V. A., Mckee-Johnson, J. W., Fonseca, R. C., Tempel, B. L., and NobenTrauth, K. (1998). Mutations in a plasma membrane $\mathrm{Ca}^{2+}$-ATPase gene cause deafness in deafwaddler mice. Nat. Genet. 19, 390-394. doi: 10.1038/1284

Strehler, E. E. (2013). Plasma membrane calcium ATPases as novel candidates for therapeutic agent development. J. Pharm. Pharm. Sci. 16, 190-206. doi: 10.18433/J3Z011

Strehler, E. E., and Zacharias, D. A. (2001). Role of alternative splicing in generating isoform diversity among plasma membrane calcium pumps. Physiol. Rev. 81, $21-50$.

Takano, Y. (1995). Enamel mineralization and the role of ameloblasts in calcium transport. Connect. Tissue Res. 33, 127-137. doi: 10.3109/03008209509016992

Tsuchiya, M., Sharma, R., Tye, C. E., Sugiyama, T., and Bartlett, J. D. (2009). Transforming growth factor-betal expression is up-regulated in maturationstage enamel organ and may induce ameloblast apoptosis. Eur. J. Oral Sci. 117, 105-112. doi: 10.1111/j.1600-0722.2009.00612.x

Vinberg, F., Wang, T., Molday, R. S., Chen, J., and Kefalov, V. J. (2015). A new mouse model for stationary night blindness with mutant Slc24a1 explains the pathophysiology of the associated human disease. Hum. Mol. Genet. 24, 5915-5929. doi: 10.1093/hmg/ddv319

Wakimoto, K., Kobayashi, K., Kuro, O. M., Yao, A., Iwamoto, T., Yanaka, N., et al. (2000). Targeted disruption of $\mathrm{Na}^{+} / \mathrm{Ca}^{2+}$ exchanger gene leads to cardiomyocyte apoptosis and defects in heartbeat. J. Biol. Chem. 275, 36991-36998. doi: 10.1074/jbc.M004035200

Wang, S., Choi, M., Richardson, A. S., Reid, B. M., Seymen, F., Yildirim, M., et al. (2014). STIM1 and SLC24A4 are critical for enamel maturation. J. Dent. Res. 93, 94S-100S. doi: 10.1177/0022034514527971

Wei, A. H., Zang, D. J., Zhang, Z., Liu, X. Z., He, X., Yang, L., et al. (2013). Exome sequencing identifies SLC24A5 as a candidate gene for nonsyndromic oculocutaneous albinism. J. Invest. Dermatol. 133, 1834-1840. doi: 10.1038/jid.2013.49

Wen, X., Lacruz, R. S., Smith, C. E., and Paine, M. L. (2014). Gene-expression profile and localization of $\mathrm{Na}^{+} / \mathrm{K}^{+}$-ATPase in rat enamel organ cells. Eur. J. Oral Sci. 122, 21-26. doi: 10.1111/eos.12106

Yang, H., Kim, T. H., Lee, H. H., Choi, K. C., and Jeung, E. B. (2011). Distinct expression of the calcium exchangers, NCKX3 and NCX1, and their regulation by steroid in the human endometrium during the menstrual cycle. Reprod. Sci. 18, 577-585. doi: 10.1177/1933719110396229

Yin, K., Lei, Y., Wen, X., Lacruz, R. S., Soleimani, M., Kurtz, I., et al. (2015). SLC26A gene family participate in ph regulation during enamel maturation. PLOS ONE 10:e0144703. doi: 10.1371/journal.pone. 0144703

Zacharias, D. A., and Kappen, C. (1999). Developmental expression of the four plasma membrane calcium ATPase (Pmca) genes in the mouse. Biochim. Biophys. Acta 1428, 397-405. doi: 10.1016/S0304-4165(99)00058-6 
Zaki, A. E., Hand, A. R., Mednieks, M. I., Eisenmann, D. R., and Borke, J. L. (1996). Quantitative immunocytochemistry of $\mathrm{Ca}^{2+}-\mathrm{Mg}^{2+}$ ATPase in ameloblasts associated with enamel secretion and maturation in the rat incisor. Adv. Dent. Res. 10, 245-251. doi: 10.1177/08959374960100022101

Zanni, G., Cali, T., Kalscheuer, V. M., Ottolini, D., Barresi, S., Lebrun, N., et al. (2012). Mutation of plasma membrane $\mathrm{Ca}^{2+}$ ATPase isoform 3 in a family with X-linked congenital cerebellar ataxia impairs $\mathrm{Ca}^{2+}$ homeostasis. Proc. Natl. Acad. Sci. U.S.A. 109, 14514-14519. doi: 10.1073/pnas.1207488109

Zhekova, H., Zhao, C., Schnetkamp, P. P., and Noskov, S. Y. (2016). Characterization of the cation binding sites in the NCKX2 $\mathrm{Na}^{+} / \mathrm{Ca}^{2+}-\mathrm{K}^{+}$ exchanger. Biochemistry 55, 6445-6455. doi: 10.1021/acs.biochem.6b00591
Conflict of Interest Statement: The authors declare that the research was conducted in the absence of any commercial or financial relationships that could be construed as a potential conflict of interest.

Copyright $\odot 2017$ Robertson, Wen, Yin, Chen, Smith and Paine. This is an openaccess article distributed under the terms of the Creative Commons Attribution License (CC BY). The use, distribution or reproduction in other forums is permitted, provided the original author(s) or licensor are credited and that the original publication in this journal is cited, in accordance with accepted academic practice. No use, distribution or reproduction is permitted which does not comply with these terms. 